\title{
Rabies post-exposure prophylaxis is not indicated following fox-related injuries occurring in France
}

Philippe Gautret ${ }^{1,2 *}$, Hervé Bourhy ${ }^{3}$

${ }^{1}$ Assistance Publique Hôpitaux de Marseille, CHU Nord, Pôle Infectieux, Institut HospitaloUniversitaire Méditerranée Infection, 13015 Marseille, France.

${ }^{2}$ Aix Marseille Université, Unité de Recherche en Maladies Infectieuses et Tropicales Emergentes (URMITE), UM63, CNRS 7278, IRD 198, Inserm 1095, Faculté de Médecine, 27 bd Jean Moulin, 13005 Marseille, France.

${ }^{3}$ Institut Pasteur, Unité Dynamique des lyssavirus et adaptation à l'hôte, National Reference Centre for Rabies, WHO Collaborating Centre for Reference and Research on Rabies, 28 rue du docteur Roux, 75724 Paris Cedex 15, France

\section{To the Editor}

The paper by Jeanpetit and colleagues, recently published in Zoonoses Public Health (Jeanpetit et al., 2013) provides valuable information about the knowledge of general practitioners regarding rabies post-exposure prophylaxis (PEP). Numerous gaps in the knowledge of primary health care providers are evidenced in this work. However, we would like to report our contradictive opinion regarding the fox rabies situation in France and the rabies PEP following fox-related bites. A mutant of the rabies virus once adapted to the dog seems to have changed vector in the 1930s to 1940s at the Russian-Polish border (Bourhy et al., 1999). A new virus adapted to the red fox appeared. The area of epizootic rabies then 
expanded rapidly in all directions, with an average progression of $20 \mathrm{~km}$ to $60 \mathrm{~km}$ per year, expanding into several countries in eastern, central and Western Europe. The maximum northsouth extension in Western Europe was reached in the late 1980s, extending from the Netherlands to Italy. The maximum extension to the west was reached in 1989, covering a large portion of the northeastern quarter of France (Bourhy et al., 2005). The first case of fox rabies was recorded in France in 1968. From 1968 to 1975, the progression of the fox rabies front from the North-east French border with Belgium, Luxembourg, Germany and Switzerland toward the center of the country was uninterrupted and the increase of incidence was exponential (Toma, 2005). Control efforts including primarily fox culling campaigns from 1968 and 'on-site' oral vaccination of foxes from 1986 led to a significant incidence decreased from 1990 until the complete disappearance of fox rabies in 1999 with the last case of fox rabies recorded at the end of December 1998 (Toma, 2005).

From the human health point of view, this fox rabies enzootic resulted in about 6.000 people receiving post exposure treatment per year at the end of the 1990s. (Rapports Epidémiologie et Prophylaxie de la rage humaine en France:

http://www.pasteur.fr/ip/easysite/pasteur/fr/sante/centres-nationaux-de-reference-et-centrescollaborateurs-de-1-oms/cnr-et-ccoms/cnr-de-la-rage/actualites-rapports)

Since 2000, France has been listed as rabies-free according to the World Organization for Animal Health (OIE) criteria. Other neighboring countries also eliminated fox rabies: Switzerland in 1998, Belgium and Luxembourg achieved rabies-free status in 2001, and Germany in 2008 (Freuling et al., 2013). In Italy, after a thirteen-year absence, fox-rabies was reintroduced in 2008, in the Udine province at the national border with Slovenia (Nouvellet et al., 2013). 
In their paper Jeanpetit and colleagues describe the case of a pregnant woman ( 8 weeks) consulting because she was scratched by a fox that she was trying to stroke in the forest (presumptively in the Franche-Comté region, in Eastern France that share a border with Switzerland) and indicate that the correct attitude is expert advice from the rabies centre + rabies vaccine + monitoring of the patient. Given that fox rabies was eradicated in France and at its borders in neighboring countries, we disagree with the authors and recommend therapeutic abstention in case of fox-related injuries but also of any kind of exposure to wildlife animal species excepted bats occurring in France. This is also in agreement with Swiss guideline which does not recommend rabies PEP following fox-related injuries occurring in Switzerland (Office fédéral de la santé publique, 2004) and with the general practice in Belgium.

Jeanpetit and colleagues also state that rabies immunoglobulin (RIG) administration would have been postponed here because of the pregnancy. Although RIG was not indicated in this case, pregnancy is not a contraindication to rabies immunoglobulin, nor is young age or immune-compromised status (WHO, 2013).

Unfortunately, there is no official French guideline addressing rabies post-exposure prophylaxis following animal-related injuries occurring in mainland France and practitioners have to rely on World Health Organization guideline which is adapted to situations occurring in rabies enzootic countries (WHO, 2013), or on expert advice given under request by the National Reference Centre for Rabies located in Institut Pasteur, in Paris. The paper by Jeanpetit et al., therefore emphasizes the need for a detailed French or European guideline to improve the knowledge of general practitioners on rabies epidemiology and PEP and to harmonize rabies PEP practices between anti-rabies treatments centers in the country in front of the rapidly changing epidemiology of rabies. 


\section{References}

Jeanpetit R., Bellanger A.P., Piotte E., Haffner-Mauvais C., Marguet P. Knowledge, Attitudes and Practices of Primary Care Physicians in the Franche-Comte Region (France) Regarding the Risk of Rabies. Zoonoses Public Health. 2013 Oct 23.

Bourhy, H., Kissi , B., Audry, L., Smreczak, M., Sadkowska-Todys, M., Kulonen, K., Tordo, N., Stohr, K., Holmes, E., 1999: Ecology and Evolution of rabies viruses in Europe. J. Gen. Virol. 80, 2545-2557.

Bourhy, H., Dacheux, L., Strady, C., Mailles, A., 2005: Rabies in Europe in 2005. Euro Surveill. 10, 213-216.

Toma, B., 2005: Fox rabies in France. Euro Surveill. 10, 220-222.

Freuling, C. M., Hampson, K., Selhorst, T., Schröder, R., Meslin, F. X., Mettenleiter, T. C., Müller, T., 2013: The elimination of fox rabies from Europe: determinants of success and lessons for the future. Philos Trans R Soc Lond B Biol Sci. 368, 20120142.

Nouvellet, P., Donnelly, C. A., De Nardi, M., Rhodes, C. J., De Benedictis, P., Citterio, C., Obber, F., Lorenzetto, M., Pozza, M. D., Cauchemez, S., Cattoli, G., 2013 : Rabies and canine distemper virus epidemics in the red fox population of northern Italy (2006-2010). PLoS One. 8, e61588.

Office fédéral de la santé publique, groupe de travail Rage, Commission suisse pour les vaccinations., Prophylaxie pré- et post-expositionnelle de la rage chez l'homme. Juillet 2004., 2004 :

(http://www.infovac.ch/index2.php?option=com_docman\&task=docget\&Itemid=27\&id=94a). 
World Health Organization, 2013: WHO Expert Consultation on Rabies. Second report.

World Health Organ Tech Rep Ser. 982, 1-139. 